\title{
Grupo de Pesquisa Tecnologias de Informação e Comunicação na Educação
}

\author{
Ceres G. B. Morais ${ }^{1}$, Luiz C. A. Macedo ${ }^{1}$, Fernanda F. Costa ${ }^{1}$, Monalisa M. de \\ Medeiros', Layon A. A. B Padre', Sonally C. Lima', Thalles R. Barbalho \\ ${ }^{1}$ Universidade Federal Rural do Semi-Árido (UFERSA) - Campus Caraúbas - Caraúbas \\ - RN - Brasil \\ ${ }^{2}$ Universidade Federal da Paraíba (UFPB) - Campina Grande - PB - Brasil \\ \{ceres, luizcarlos\}@ufersa.edu.br, grupoeducacaodigital@gmail.com
}

Resumo. Este artigo apresenta o grupo de pesquisa "Tecnologias de Informação e Comunicação na Educação”, seus objetivos e ações em andamento.

\begin{abstract}
This paper presents the research group "Information and Communication Technologies in Education", their goals and actions in progress.
\end{abstract}

\section{Introdução}

O grupo de pesquisa "Tecnologias de Informação e Comunicação na Educação" nasce da necessidade de propiciar ao ambiente escolar um artefato didático-pedagógico que venha potencializar a aprendizagem de conceitos nas diferentes áreas do conhecimento, através da inserção de tecnologias em sala de aula.

Atualmente, o grupo é composto por uma professora coordenadora, um professor colaborador e quatro alunos bolsistas, todos da Universidade Federal Rural do SemiÁrido (UFERSA) Campus Caraúbas/RN. Além disso, conta com o apoio da UFERSA e da Secretaria Municipal de Educaçao e Cultura de Caraúbas/RN.

\section{Objetivos}

O grupo tem como objetivos: conhecer métodos de inserção da Informática na Educação; desenvolver novas metodologias para a prática do ensino-aprendizado com a utilização de novas tecnologias, utilizando softwares livres já existentes; atuar em ações extensionistas capacitando professores quanto a utilização de novas tecnologias de informação e comunicação em sala de aula.

\section{Principais projetos}

Atuamente, o grupo desenvolve o projeto de extensão "Utilização de Softwares Educativos como elemento facilitador do processo ensino aprendizado", fomentado pela Pró-Reitoria de Extensão e Cultura (PROEC) da UFERSA.

Além disso, o grupo aprovou o projeto de extensão "Informática na educação: utilização de softwares educativos como mediadores do processo ensino-aprendizagem" no edital PROEXT 2014, o qual será fomentado pelo MEC/PROEXT. 